but important message: urinary investigation is an essential examination in any infant or child presenting with jaundice.

1 Arthur, A. B., and Wilson, B. D. R., British Medical fournal, 1967, 1, 539. 2 Görter, E., and Lignac, G. O. E., Archives of Disease in Childhood, 1928, 3, 232.

${ }^{3}$ Ng, S. H., Rawstron, J. R., Archives of Disease in Childhood, 1971, 46, 173.

4 Kenny, J. F., Medearis, D. N., jun., Klein, S. W., Drachman, R. H. and Gibson, L. E., Fournal of Pediatrics, 1966, 68, 530

Seeler, R. A., and Hahn, K., American fournal of Diseases of Children $1969,118,553$

Neale, G., Caughey, D. E., Mollin, D. L., and Booth, C. C., British Medical fournal, 1966, 1, 382.

7 Bernstein, J., and Brown, A. K., Pediatrics, 1962, 29, 873.

8 Herman, R. H., and Sullivan, B. H., jun., American fournal of Medicine, $1959,27,154$

${ }^{9}$ Hamilton, J. R., and Sass-Kortsak, A., fournal of Pediatrics, 1963, 63, 121.

10 Winckel, F., Deutsche medizinische Wochenschrift, 1879, 24, 303.

${ }^{11}$ Sweet, A. Y., and Wolinisky, E., Pediatrics, 1964, 33, 865.

\section{Treatment with Growth Hormone}

Widespread interest in the use of human growth hormone followed M. S. Raben's ${ }^{1}$ successful treatment of a 17-yearold boy with pituitary failure. During the past decade the results of several studies on the effects of long-term growth hormone therapy have been published. Human pituitary glands obtained post mortem are still the only useful source of growth hormone, and schemes for collecting such glands are operating in a number of countries. The Medical Research Council's Human Pituitary Hormone Subcommittee is responsible for collection of pituitary glands and the distribution of the hormone in the United Kingdom. At present about 75 patients in this country are receiving growth hormone treatment.

The indications for long-term growth hormone therapy are now fairly clearly defined. With the possible exception of occasional cases of hypoglycaemia ${ }^{2} 3$ it now appears that the only patients who are likely to derive real benefit from such treatment are children who are abnormally small as a result of deficiency of growth hormone, the deficiency occurring either as an isolated defect or as part of a more general anterior pituitary failure. Early hopes that growth hormone might be of value in the management of a variety of disorders associated with failure to grow have not been fulfilled. Though acceleration of growth has been reported in patients with Turner's syndrome, ${ }^{4}$ achondroplasia, ${ }^{5}$ Silver's syndrome, ${ }^{6}$ and constitutional short stature, ${ }^{7}$ the effects have been inconsistent and poorly sustained, and it is now widely accepted that growth hormone therapy is of no help to such patients.

While deficiency of growth hormone can often be suspected on clinical grounds, it is essential that the diagnosis is established as firmly as possible if prolonged periods of ineffective and wasteful therapy are to be avoided. During recent years radioimmunoassay methods for growth hormone have become more widely available, and estimation of its level in the plasma after stimuli such as insulininduced hypoglycaemia ${ }^{8}$ or infusion of arginine ${ }^{9}$ has largely replaced diagnostic tests based on the acute metabolic effects of growth hormone. ${ }^{10}$ An absent or impaired production of growth hormone in the plasma during two or more such provocative tests provides strong evidence of complete or partial deficiency of it.

With few exceptions ${ }^{11}$ good results have been obtained in the long-term therapy treatment of most patients deficient in growth hormone. During the early phases of treatment acceleration of growth can be expected, and growth rates between $8 \mathrm{~cm} /$ year and $12 \mathrm{~cm} /$ year are common. At this time the subcutaneous fat oft $' n$ diminishes. Rapid growth does not continue indefinitely. and the rate slowly declines to normal or below-nurmal levels. As a result the patient may not fully reach his "expected" height, particularly when treatment has been long delayed. When treatment is discontinued, growth slows down, often to below the pretreatment rate, but reintrodu :tion of treatment leads to further acceleration of growtl:. Bone maturation occurs during treatment, but disproportionate advance in bone age, a feature of androgen-induced growth, is not seen. In a few older patients with isolated deficiency of growth hormone treatment appears to have initiated puberty. ${ }^{12}$

The treatment regimen which allows the most efficient use of the hormone is still to be determined. Good responses have been obtained with a weekly dose of hormone as small as $2.5 \mathrm{mg},{ }^{13}$ but in most centres higher doses have been used. In general, most patients have been treated with twice- or thrice-weekly injections of hormone, but weekly administration has also been reported to be effective. ${ }^{13}$ It is still uncertain whether patients with complete anterior pituitary failure require thyroid supplements, ${ }^{14}$ 15 but it is generally agreed that corticosteroid supplements should be withheld, as relatively small doses of cortisone may reduce the response to treatment. ${ }^{16}$

Growth hormone therapy has been remarkably free from side effects. While anorexia and oliguria were reported during early studies on the acute metabolic effects of growth hormone in man, ${ }^{17}$ they have not been a problem during long-term therapy. Growth hormone has a diabetogenic action, but impaired carbohydrate tolerance has not been reported as a result of the long-term treatment of growthhormone-deficient children. The low blood sugar values commonly found in such patients return to normal as a result of treatment and symptomatic hypoglycaemia is relieved. ${ }^{18} 19$ A number of patients with craniopharyngioma have been treated with growth hormone after partial resection of the tumour; there is no evidence to suggest that such treatment accelerates growth of any residual tumour. Occasionally the patient's rate of growth returns to normal after surgical resection of a craniopharyngioma ${ }^{20}$ and growth hormone therapy is then not indicated.

In some series of patients treated with growth hormone a high incidence of anti-growth-hormone antibodies has been found. $14 \quad 152122$ In most cases the antibodies have been of low titre and do not appear to have been of clinical significance. Rashes and other evidence of hypersensitivity have not been noted, and the patients have continued to respond to treatment. In a minority of patients very high antibody titres have developed, and in many of these cases growth hormone was no longer effective. ${ }^{14} \quad 15 \quad 22 \quad 23$ In some instances the antibody titre fell when treatment was discontinued, and further growth hormone therapy was successful. ${ }^{22} 24$ In others the high antibody titres persisted and treatment had to be abandoned. 2224 The mechanisms underlying the formation of antibody during treatment with different preparations of human growth hormone are still incompletely understood. Chemical changes of the hormone may occur during extraction or lyophilization ${ }^{25}$ and may account for its antigenicity. However, additional factors may be responsible for the high antibody titres found in a minority of patients. Recently R. Illig ${ }^{24}$ described four children with a familial form of growth hormone deficiency who developed very high anti- 
body titres while on treatment, and she suggested that antenatal deficiency of growth hormone may have prevented development of immune-tolerance to the hormone. It would be of interest to learn whether chorionic somatomammotrophin, a placental protein present in the fetal circulation and which has a close immunochemical similarity to growth hermone, ${ }^{26}$ is equally antigenic in these patients.

i Raben, M. S., Fournal of Clinical Endocrinology and Metabolism, 1958, 18,

901.
${ }^{2}$ Mahon, W. A., Mitchell, M. L., Steinke, J., and Raben, M. S., New England $\dot{f}$ ournal of Medicine, 1962, 267, 1179

3 Soyka, L. F., Molliver, M., and Crawford, J. D., Lancet, 1964, 1, 1015.

4 Sovka, L. F., Ziskind, A., and Crawford, J. D., New England fournal of Medicine, 1964, 271, 754.

5 Gershberg, H., Mari, S., Hulse, M., and St. Paul, H., Metabolism, 1964, 13, 152 .

- Tanner, J. M., and Ham, I. J., Archives of Disease in Childhood, 1969, 44, 231.

${ }^{7}$ Raben, M. S., New England Fournal of Medicine, 1962, 266, 82.

${ }^{8}$ Roth, J., Glick, S. M., Yalow, R. S., and Berson, S. A., Science, 1963, 140, 987.

Knopf, R. F., et al., fournal of Clinical Endocrinology and Metabolism,

10 Prader, A., Illig, R., Szeky, J., and Wagner, H., Archives of Disease in

1 Childhood, 1964, 39, 535 .

12 Goodman, H. G., Grumbach, M. M., and Kaplan, S. L., New England Fournal of Medicine, 1968, 278, 57 .

13 Rosenbloom, A. L., Ұournal of the American Medical Association, 1966,

14 198, 364. Paediatrica Acta, 1967, 22, 423.

${ }^{15}$ Root, A. W., Bongiovanni, A. M., and Eberlein, W. R., fournal of Pediatrics, $1971,78,737$.

16 Soyka, L. F., and Crawford, J. D., Fournal of Clinical Endocrinology and Metabolism, 1965, 25, 469 .

17 Bergenstal, D. M., et al., fournal of Laboratory and Clinical Medicine, $1957,50,791$.

18 Nadler, H. L., Neumann, L. L., and Gershberg, H., Fournal of Pediatrics, 1963, 63, 977.

19 Wilber, J. F., and Odell, W. D., Metabolism, 1965, 14, 590.

${ }^{20}$ Holmes, L. B., Frantz, A. G., Rabkin, M. T., Soeldner, J. S., and Crawford, J. D., New England fournal of Medicine, 1968, 279, 559

21 Kaplan, S. L., Abrams, C. A., Bell, J. J., Conte, F. E., and Grumbach, M. M., Pediatric Research, 1968, 2, 43.

22 Chalkley, S. R., and Tanner, J. M., Archives of Disease in Childhood, 1971, 46, 160.

${ }^{23}$ Parker, M. L., Mariz, I. K., and Daughaday, W. H., Fournal of Clinical Endocrinology and Metabolism, 1964, 24, 997.

Illig, R., Fournal of Clinical Endocrinology and Metabolism, 1970, 31, 679.

${ }^{25}$ Lewis, U. J., et al., Endocrinology, 1969, 84, 332.

86 Grumbach, M. M., Kaplan, S. L., Sciarra, J. J., and Burr, I. M., Annals of the Nerv York Academy of Sciences, 1968, 148, 501.

\section{Microaneurysms in Diabetic Retinopathy}

Microaneurysms in the eyes of patients with diabetic retinopathy were reported back in $1879,{ }^{1}$ but it was not until A. J. Ballantyne and A. Loewenstein ${ }^{2}$ described them again in 1943 that their relationship with diabetes was firmly established. They are not specific to diabetes and occur in a number of unrelated conditions such as macroglobulinaemia, hypertension, venous occlusion, sickle-cell disease, and pulseless disease. ${ }^{3}$

Clinically they are difficult to distinguish from small haemorrhages, and the two are rightly regarded together as "dots" and "blots," or the "sanguinolent spots" of $\mathrm{K}$. Lunbaek. ${ }^{4}$ If few in number, they are diffusely scattered in the fundus. In more advanced retinopathy they usually occur in clusters of small numbers away from large vessels, more commonly in the posterior pole, and they vary somewhat in size. They can also be found in the centre of rings of hard exudates and may contribute to their formation.

Microscopically the majority are seen as diverticula of the basement membrane of capillaries, ${ }^{5}$ but some may contain hyaline material in the wall ${ }^{6}$ or may be hypercellular owing to endothelial proliferation. The pathogenesis is uncertain. A proportion are due to the formation of pouches in the basement membrane of abnormal capillaries, and as they tend to be adjacent to areas of capillary closure anoxia probably plays a part. Endothelial proliferation is thought to be a secondary phenomenon and not the primary cause of their formation. ${ }^{5} \mathrm{~A}$ small number arise as a result of capillaries forming U-shaped loops with resultant disappearance of the adjacent walls, but stagnation and engorgement, a feature of the microcirculation in diabetic retinopathy, may also be important factors. ${ }^{5}$

Much of our knowledge has stemmed from histological studies, ${ }^{89}$ but the application of fluorescence angiography to the study of diabetic retinopathy ${ }^{10}$ has yielded more useful information still. Where both the fluorescence angiogram and histological preparations were available it was possible to correlate many of the features. ${ }^{11} 12$ Thus microaneurysms were found to surround areas not perfused by capillaries, and histologically these areas were seen to contain closed acellular capillaries. Fluorescein angiography showed many more microaneurysms than were seen clinically, and in an admirable study of their rate of formation and disappearance E. M. Kohner and C. T. Dollery ${ }^{12}$ found that some were perfused intermittently. They studied the serial angiograms of 21 patients chosen out of 100 who had had serial fluorescein angiography, because they had at least three angiograms of good quality in the follow-up period of 18 months. They counted the microaneurysms in a given area of the retina by mapping them on a diagram. By repeating the process serially and plotting those that had disappeared and appeared afresh, they were able to calculate the monthly rate of formation and disappearance of the lesions. Their patients were divided into three groups: "mild" cases, requiring no specific treatment for their retinopathy; "severe" cases suitable for treatment by pituitary ablation but not subjected to it; and a similar group treated by pituitary ablation. They did not find a statistically significant difference between the rates of formation and disappearance of microaneurysms in cases with "severe" and "mild" retinopathy, but they did find a significant difference in the rates between those with "severe" retinopathy and those who had been treated by pituitary ablation. In the latter group, both the rate of formation was slower and the rate of disappearance greater than in the untreated group.

As well as recording a quantitative way of studying the course of microaneurysms this study supplied some evidence to support claims that pituitary ablation has a beneficial effect on diabetic retinopathy. Despite the difficulty of distinguishing microaneurysms from bends in capillaries, such a quantitative method of assessment is a useful contribution to studying their role in diabetic retinopathy and in assessing the effect of different types of treatment.

1 Mackenzie, S. G., Ophthalmic Hospital Reports, 1877, 9, 134.

Ballantyne, A. J., and Loewenstein, A., Transactions of the Ophthalmological Society of the United Kingdom, 1943, 63, 95.

3 Duke-Elder, S., System of Ophthalmology, p. 163. London, Henry Kimpton, 1967.

4 Lunbaek, K., Long-term Diabetes. Copenhagen, Munksgaard, 1953.

5 Ashton, N., British fournal of Ophthalmology, 1963, 47, 521.

- Bloodworth, J. M. B., Diabetes, 1962, 11, 1.

Kuvrabara, T., and Cogan, D. G., Archives of Ophthalmology, 1960, 64, 904.

Ashton, N., British fournal of Ophthalmology, 1950, 34, 38.

Scott, D. J., Dollery, C. T., Hill, D. W., Hodge, J. V., and Fraser, R., British Medical fournal, 1964, 1, 811.

${ }^{10}$ De Venecia, G., and Davis, M. D., Investigative Ophthalmology, 1967, 6, 555.

${ }^{11}$ Kohner, E. M., and Henkind, P., American fournal of Ophthalmology, $1970,69,403$.

${ }^{12}$ Kohner, E. M., and Dollery, C. T., European Fournal of Clinical Investigation, 1970, 1, 167 